\title{
柔軟植生流れの物質輸送メカニズムへの大規模 組織渦の寄与に関する実験的研究
}

\author{
岡本 隆明 1 ・ 山上 路生 2 \\ 1正会員 京都大学大学院助教 社会基盤工学専攻（７615-8540 京都市西京区京都大学桂） \\ E-mail: takaaki.okamoto@water.kuciv.kyoto-u.ac.jp \\ 2正会員 京都大学大学院准教授 社会基盤工学専攻（７６15-8540 京都市西京区京都大学桂） \\ E-mail: michio.sanjou@water.kuciv.kyoto-u.ac.jp
}

\begin{abstract}
開水路植生流れでは, 大規模な組織渦が浮遊砂や栄養塩類などのスカラー輸送を支配するが, その詳細 については不明な点が多い. 特に本稿では沈水植生の摇動と乱流拡散特性の関係にフォーカスし, その定 量評価を試みた。剛体植生モデルと柔軟植生モデルを用いた実験水路において，レーザー蛍光誘起法(LIF 法)による染料濃度計測と PIV 法を併用した乱流計測を実施した．前半部では剛体および柔軟植生によって 生成される渦のスケールや移流速度を比較した。後半部では濃度と流速の瞬間場の同時計測データより, 染料濃度と流速の相関特性を考察した。さらにスカラーフラックスを直接計算し, 柔軟植生が摇動するこ とで植生層内部への物質輸送効率が小さくなることが示された.
\end{abstract}

Key Words : flexible-vegetation, turbulence transport, coherent vortices, vertical scalar flux, LIF, PIV

\section{1. はじめに}

自然の力によって植生を繁茂させ, 水生生物の再 生をはかることは多自然型川づくりの真髄の一つで あろう。これまでの取り組みによって河川生物の生 息環境は徐々に再生してきているものの, 施工後か えって河川環境を悪化させた残念な事例もみられる. 多くの場合事前調查が不十分なまま過去の事例に従 って経験則に基づいて行われている点が課題として あげられる ${ }^{1)}$. 今後, 植生の河川環境への影響を正 確に把握し, 経験則のみに頼らない河川事業を展開 するためには，植生と流れの相互作用の基礎学理を 構築することも大変重要である。

本研究では特に沈水植生の流れ場をハイライトす る.これまでの植生研究は抵抗則の解明が中心であ った. Kouwen \& Unny $(1973)^{2}$ は種々の剛性の異なる 植生モデルを用いた水路実験を行い, 植生の変形量 と流れ場のパラメーターとの関係式を求めた. 清水 ら(1992) 3) は植生による形状抵抗項を運動量式に加え ることで植生層内外の流速分布を良好に再現した。 大本ら $(2005)^{4)}$ は水路中央に設置した植生群落を横断 寸る流れに着目し, 水面変動や乱流構造に与える影 響を明らかにした。

一方, 実河川の植生は柔軟性を有し, 植生高さよ
りかぶり水深が大きい流れにおいて植生が群体的に 摇動する「藻波(Monami)現象」がみられる. 池田ら $(1996)^{5)}$ は PIV 計測を用いて藻波の発生機構を研究し, 大規模組織渦が流下方向に伝わることがその主因で あるとした。辻本ら (1996) $)^{6}$ は植生の摇動自体が流れ 場に影響する，すなわち植生の摇動と流れの相互作 用によって付加的な運動量交換が発生することが十 分に考えられるとした. Siniscalchi \& Nikora (2013) は超音波流速計測とビデオ撮影を同時に行い, 抗力 変動, 植生摇動, 乱流変動の相関を周波数解析によ って考察した．また数值モデルも現象解明の有効な 手法であり植生摇動と乱流渦の関倸は個々の組織渦 の抽出や追跡が可能となった ${ }^{8)}$. さらに著者ら $(2016)^{9)}$ のグループは柔軟植生の運動が流れ場に与え る効果に着目し，PIV と PTV 法を併用することで柔 軟植生の先端変位と瞬間流速を同時計測した. 藻波 発生時には植生間の摇動コヒーレンスが増加するこ とを明らかにした。

最近では流れ構造だけでなく, 植生に誘起される 大規模渦による物質輸送や乱流拡散についての研究 も進んでいる. Rahman \& Webster (2005) ${ }^{10)}$ はレーザ 一蛍光誘起法(LIF)法を用いて滑面と粗面流れにおい て濃度計測し, 時間平均・乱流統計量を比較した。 粗面流れでは乱流拡散が大きくなり, 物質交換が促 

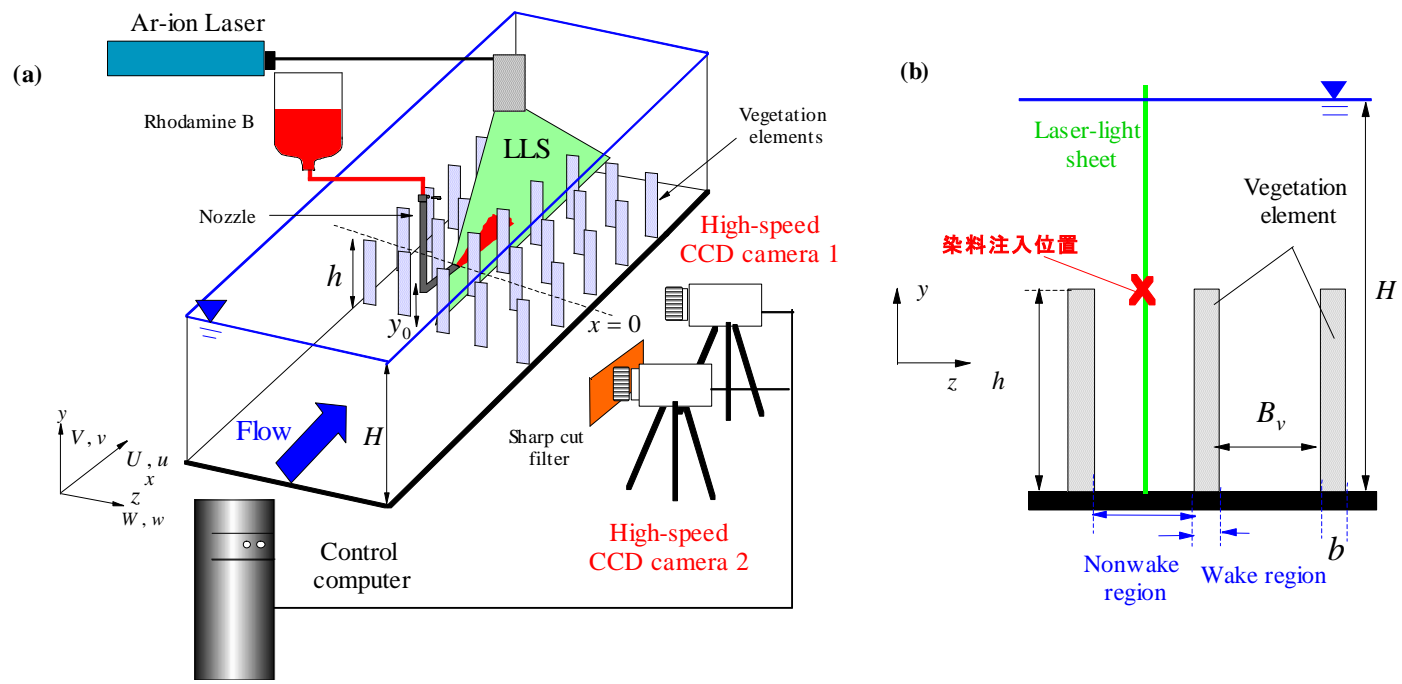

図-1 実験装置図 (a) PIV/LIF 同時計測システム,

(b) LLS の照射位置

進されることを報告している。 Reidenbach ら $(2007)^{111}$ は水路底面にサンゴ植生を配置し LIF 法に よる計測を行った，植生表面に薄くローダミンを塗 って拡散実験し，植生密度の大小，水面波の有無に よって植生層内外の物質輸送効率が変化することを 解明した. Ghisalberti \& Nepf $\left.(2008)^{12}\right)$ は仮想粒子法 を用いて柔軟植生流れ場の拡散特性について考察し, 藻波現象の発生により乱流拡散が減少することを数 值予測している。.さらに柔軟植生場における土砂輸 送やせん断応力についても研究が進展している ${ }^{13)}$.

以上のように，植生流れの研究は国内外を問わず， 非常に興味深いトピックスである. 特に物質輸送メ カニズムに関する研究は, 植生流れでは組織渦が栄 養塩, 溶存ガス, 浮遊砂などスカラー輸送に大きく 寄与寸ると考えられるため, 河川環境上重要である. これらの乱流輸送現象を理解寸るには, 流れ場の瞬 時速度と拡散されるスカラー量の瞬時值を同時に計 測する必要がある。そこで本研究では, 植生密度・ 剛性を系統的に変化させて, LIF 法と PIV 法を併用 し，染料濃度と瞬間流速の多点同時計測を行い，全 水没状態の植生流れにおける物質輸送メカニズムを 明らかにする。

\section{2. 実験システム}

\section{(1) PIV / LIF 実験装置}

本研究で用いた実験水路は, 全長 $10 \mathrm{~m}$, 幅 $40 \mathrm{~cm}$, 高さ $50 \mathrm{~cm}$ の可変勾配型水路である ${ }^{9)}$. 図-1(a)は計 測システムおよび座標系を示したものである，座標 系は流下方向に $x$ 軸, 鉛直方向に $y$ 軸, 横断方向に $z$ 軸を設定し, 染料注入ノズル先端を $x=0$, 河床
を $y=0$ とした。それぞれの方向における瞬間流速 を $\tilde{u}, \tilde{v}$ おび $\tilde{w}$, 時間平均流速を $U, V$ および

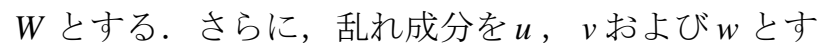
る。同様に, 染料の瞬間濃度を $\tilde{c}$, 時間平均濃度を $C$, 乱れ成分を $c$ とするすなわち, $\tilde{u}=U+u$, $\tilde{v}=V+v, \quad \tilde{w}=W+w, \quad \tilde{c}=C+c$ である. $H$ は水深 である。

水路上流側 $2 \mathrm{~m}$ 区間を滑面区間とし，水路下流側 $8 \mathrm{~m}$ の区間にわたって植生模型を正方格子状に配置 した。本研究では剛体植生 $(h=50 \mathrm{~mm}, b=8 \mathrm{~mm}$, $t_{h}=1 \mathrm{~mm}$ : アクリル板) と柔軟植生モデル $(h=70 \mathrm{~mm}$, $b=8 \mathrm{~mm}, t_{h}=0.1 \mathrm{~mm}:$ OHPフィルム)を用いた。ここで $h$, $b, t_{h}$ はそれぞれモデルの高さ, 幅, 厚さである。岡 体植生と柔軟植生高さを変化させているのは柔軟植 生が折れ曲がったときの植生高さを剛体植生高さと 同程度とするためである．植生モデルの曲げ剛性 $J$ $(=E \times I)$ は $J=7.3 \times 10^{-5} \mathrm{Nm}^{2}$ で, 既往研究 $\left.{ }^{14)}, 15\right)$ の植 生モデルと同オーダーである。柔軟植生の直立高さ をh，折れ曲がったときの高さを $h_{d}$ とする， $L_{v}$ と $B_{v}$ はそれぞれ，隣り合う植生模型の流下方向およ び横断方向の配置間隔である.

本研究では流れ場の瞬間流速一濃度を同時計測す るために, 2 台の高速度 CCD カメラ $(1024 \times 1024$ pixel）を用いた。それぞれ PIV 用および LIF 用であ る. 2 台のカメラはパルスジェネレータからのトリ ガー信号により同期をとることが可能である，光源 として $3 \mathrm{~W}$ の連続アルゴンイオンレーザーを用いて 厚さ $2 \mathrm{~mm}$ のレーザーライトシートを水路上方から $x$ 軸と平行に照射した。乱流構造が十分に発達してい ると考えられる植生群落の上流端から $5 \mathrm{~m}$ の位置に 高速度 CCD カメラを設置した. 図-1(b)に示すよう 
表-1 実験ケース

\begin{tabular}{|ccccccccc|c|}
\hline Case & $\Phi$ & $H(\mathrm{~cm})$ & $h(\mathrm{~cm})$ & $H / h$ & $U_{m}(\mathrm{~cm} / \mathrm{s})$ & $\mathrm{Fr}$ & $\mathrm{Re}$ & $\begin{array}{c}\text { Classification } \\
\text { of plant motion }\end{array}$ & Method \\
\hline R-a & 0.243 & 15.0 & 5.0 & 3.0 & 20.0 & 0.17 & 30000 & Rigid & PIV \\
R-b & 0.137 & 15.0 & 5.0 & 3.0 & 20.0 & 0.17 & 30000 & Rigid & PIV \\
R-c & 0.061 & 15.0 & 5.0 & 3.0 & 20.0 & 0.17 & 30000 & Rigid & PIV, LIF \\
R-d & 0.034 & 15.0 & 5.0 & 3.0 & 20.0 & 0.17 & 30000 & Rigid & PIV \\
R-e & 0.022 & 15.0 & 5.0 & 3.0 & 20.0 & 0.17 & 30000 & Rigid & PIV \\
R-f & 0.015 & 15.0 & 5.0 & 3.0 & 20.0 & 0.17 & 30000 & Rigid & PIV, LIF \\
\hline F-a & 0.243 & 21.0 & 7.0 & 3.0 & 20.0 & 0.14 & 42000 & Monami & PIV \\
F-b & 0.137 & 21.0 & 7.0 & 3.0 & 20.0 & 0.14 & 42000 & Monami & PIV \\
F-c1 & 0.061 & 21.0 & 7.0 & 3.0 & 10.0 & 0.07 & 21000 & Swaying & PIV \\
F-c2 & 0.061 & 21.0 & 7.0 & 3.0 & 20.0 & 0.14 & 42000 & Monami & PIV, LIF \\
F-d & 0.034 & 21.0 & 7.0 & 3.0 & 20.0 & 0.14 & 42000 & Monami & PIV \\
F-e & 0.022 & 21.0 & 7.0 & 3.0 & 20.0 & 0.14 & 42000 & Swaying & PIV \\
F-f & 0.015 & 21.0 & 7.0 & 3.0 & 20.0 & 0.14 & 42000 & Swaying & PIV, LIF \\
\hline Smooth & 0.0 & 21.0 & - & 3.0 & 20.0 & 0.14 & 42000 & - & PIV, LIF \\
\hline
\end{tabular}

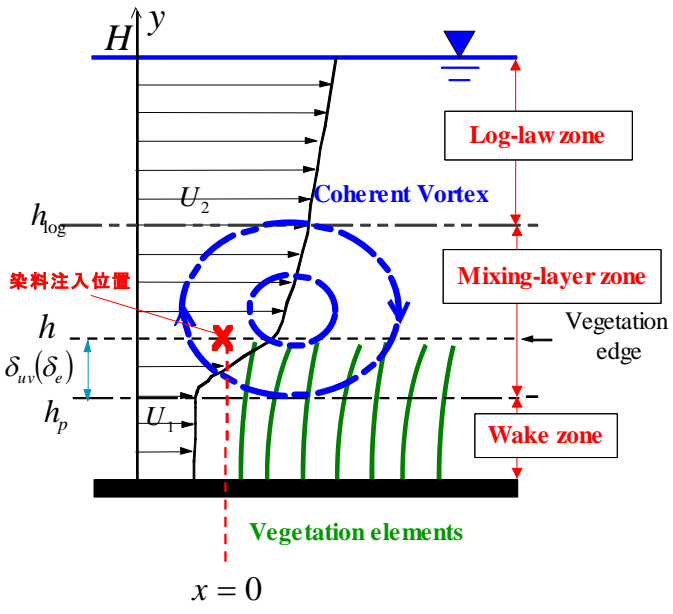

図-2 植生流れの領域区分と染料の注入位置

に横断方向の LLS 照射位置は，個々の植生の wake の影響が少ない植生間領域（non-wake region）16)に 設定した.この $x-y$ 平面を 2 台のカメラで撮影し, 瞬間流速 2 成分 $(\tilde{u}(t), \tilde{v}(t))$-濃度 $\tilde{c}(t)$ を同時計測した。 撮影領域サイズは $30 \mathrm{~cm} \times 30 \mathrm{~cm}$ である.

PIV 計測ではトレーサーとして粒径 $100 \mu \mathrm{m}$, 比重 1.02 のポリスチレン粒子を用い, 画像の輝度值から 濃度相関法によって瞬間流速ベクトルを算出した. 高速カメラに外部トリガー信号を与えて， $500 \mathrm{~Hz}$ の フレームレートで 2 枚の連続画像のペアを 60 秒間撮 影した. PIVのサンプリング周波数は $30 \mathrm{~Hz}$ である.

一方, LIF 用のカメラにはシャープカットフィル タを装着しており，レーザー光で誘起されたローダ ミンの発光のみを撮影できる.ノズルは内径 $3 \mathrm{~mm}$ のステンレス製のものを用い，ローダミン B を染料 として水中に注入した。注入の横断方向位置はレー ザーライトシート（LLS）位置に一致させ，ノズル は $x$ 軸に平行になるようにした。 なお, 染料の注入 速度は, 注入高さ $\left(y_{0}=h\right)$ における時間平均局所流速 $U(h)$ に一致するように調整している.

LIF 計測ではレーザー光強度が画像端部で低下す
るため, 本研究ではピクセルごとにレーザー光強度 に関する補正係数を算出してキャリブレーションを 行っている。計測領域全体にかかる大きさのプレキ シガラス製の容器に種々の一定濃度のローダミン $\mathrm{B}$ 溶液を満たして撮影する予備実験を行い，1 ピクセ ルごとに次式のような濃度 $c$ とローダミン $\mathrm{B}$ による 発光強度 $I$ の線形関係式を確認した。

$$
c(i, j)=a(i, j) I(i, j)+b(i, j)
$$

添え字 $i, j$ は画像内の pixel 位置を表す。予備実験の 結果，ローダミン B 濃度 $0-0.6 \mathrm{mg} / 1$ では線形関係が 成立することが確認できた。

\section{(2) 実験ケース}

表-1 は水理条件でかぶり水深比 $H / h=3.0$ は一定と して，植生密度 $\phi$ を系統変化させている。ここでの $U_{m}$ は断面平均流速で, レイノルズ数は $\mathrm{Re} \equiv U_{m} h / v \quad(v$ は動粘性係数），フルード数は $F r \equiv U_{m} / \sqrt{g h}$ である（ $g$ は重力加速度）。また本 研究において, 植生密度 $\phi=a b$ （ $a$ は単位体積あた りの植生の投影面積, $b$ は植生モデルの幅）で算出 した.

$$
a=\frac{\text { total frontal area }}{\text { volume of vegetation layer }}=\frac{A}{V_{o}}=\frac{n \bar{h}_{d} b}{\bar{h}_{d} \cdot A_{b}}
$$

ここで $A_{b}$ は植生領域の底面積, $n$ は面積上の領域に 存在する植生要素の本数, $A$ は植生の投影面積の合 計. 表中の Swaying は植生が個々に摇動している状 態, Monami は植生が組織的に摇動している状態を示 す.

図-2 に拡散実験の染料注入位置と領域区分図を示 す。植生開水路流れは鉛直方向に流れが複雑に変化 するので，前報の研究 16)で植生流れ場は次の 3 つの 


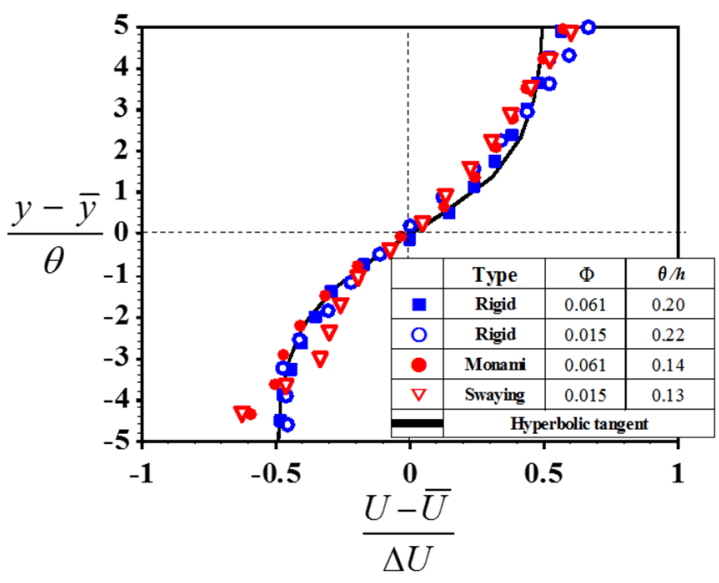

図-3 時間平均主流速の鉛直分布

領域に区分できることがわかっている.

Wake zone $\left(0 \leq y \leq h_{p}\right)$

Mixing-layer zone $\left(h_{p} \leq y \leq h_{\log }\right)$

Log-law zone $\left(h_{\log } \leq y \leq H\right)$

$h_{p}$ はレイノルズ応力 $-\overline{u v}$ の $10 \%$ となる高さ, $h_{\log }$ は Log-law zone の下端で対数則分布からのずれで評 価した ${ }^{16)}$. $U_{1}$ と $U_{2}$ は混合層の低速側流速および高 速側流速の代表值で，それぞれ混合層の下端 $h_{p}$ と 上端 $h_{\log }$ の流速とした. Nepf \& Ghisalberti (2008) ${ }^{17)}$ は Mixing-layer zone において植生層内外の物質交換が 活発になることを指摘したが，植生流れにおいて組 織渦の挙動と渦によって拡散されるスカラー量を同 時計測した例はなく, 詳細な実験データは得られて いない. そこで本研究では混合層の物質輸送への寄 与を調べるために染料注入位置は Mixing-layer zone の中心である植生先端 $\left(y_{0} / h=1.0\right)$ とした.

\section{PIV 計測による組織渦構造の比較}

\section{(1) 2次元混合層とのアナロジー}

はじめに，本研究で形成した植生開水路流れの基 本的な特性について列挙する。これまでの研究から 植生流れの流速分布は植生先端部で変曲点をもち, 混合層と良く似た性質をもつことが知られている ${ }^{17)}$. 植生が柔軟性を有するときの混合層との類似性やス ケールについて考察する。図-3は柔軟植生と剛体植 生の $\phi=0.061,0.015$ のケースについて混合層で成立 する次式で示される hyperbolic tangent 型の流速分布 18)と比較した.

$$
\frac{U-\bar{U}}{\Delta U}=\frac{1}{2} \tanh \left(\frac{y-\bar{y}}{2 \theta}\right)
$$

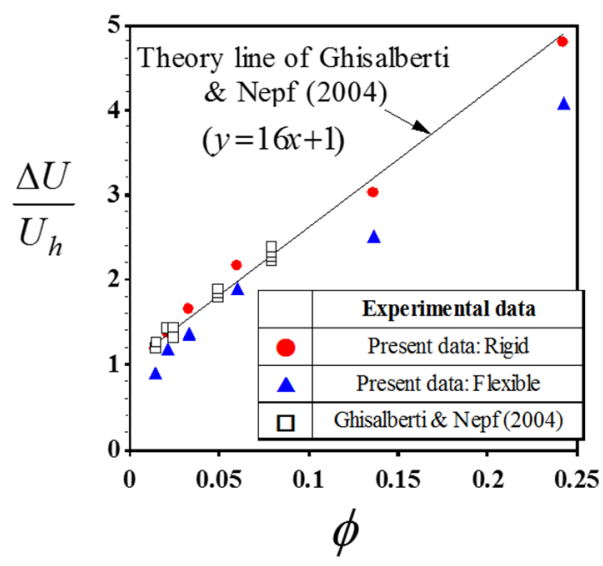

図-4 植生層内外の流速差の植生密度に対する変化

ここで $\bar{U}=1 / 2\left(U_{1}+U_{2}\right), \quad \Delta U=U_{2}-U_{1}, \quad \theta$ は運動 量厚さで次式から決定される16).

$$
\theta=\int_{0}^{\infty}\left[\frac{1}{4}-\left(\frac{U-\bar{U}}{\Delta U}\right)^{2}\right] d y
$$

柔軟植生ケースでも剛体植生と同様に植生先端付近 の流速分布が tanh 型分布に近い構造をもつのが観察 される。図中には $\theta$ の值を併示したが, 剛体植生で $\theta$ が大きくなる傾向がみられ，注目される．これよ り剛体植生流れでは柔軟植生より大きなせん断層が 発達すると考えられる.

柔軟植生と剛体植生の流速の減速効果を調べるた めに図-4には柔軟植生と剛体植生のケースについて 混合層の高速側流速と低速側流速の流速差 $\Delta U=U_{2}-U_{1}$ を示したものである. 值は植生先端流 速 $U_{h}$ で無次元化している. 植生密度が大きくなる と $\Delta U$ も増加する傾向が観察される. これは植生抵 抗が植生内部で大きくなるためであると考えられる 本研究の結果は Ghisalberti \& Nepf (2004) ${ }^{19)} の$ 結果と 良く一致しており，本論文の混合層の領域区分が妥 当であることが確認できる。また柔軟植生より剛体 植生の方が $\Delta U$ が大きくなっているため, 剛体植生 ケースで減速効果が大きいことが推測される.

\section{（2）運動量輸送メカニズム}

柔軟植生(Swaying, Monami) と岡体植生の運動量輸 送効率を調べるために図-5は同一の植生密度のケー ス $(\phi=0.061)$ にいてレイノルズ応力 $-\overline{u v}$ 分布を比 較した. 值は断面平均流速 $U_{m}$ で無次元化している. $-\overline{u v} / U_{m}^{2}$ は運動量交換を表すパラメーターであるこ とが知られている20). 剛体植生や Swaying ケースで は植生先端で大きなピーク值をもつため，植生先端 


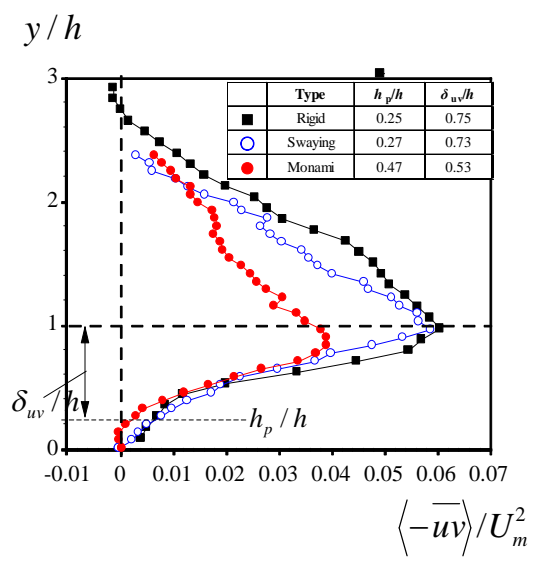

図-5 レイノルズ応力分布の比較

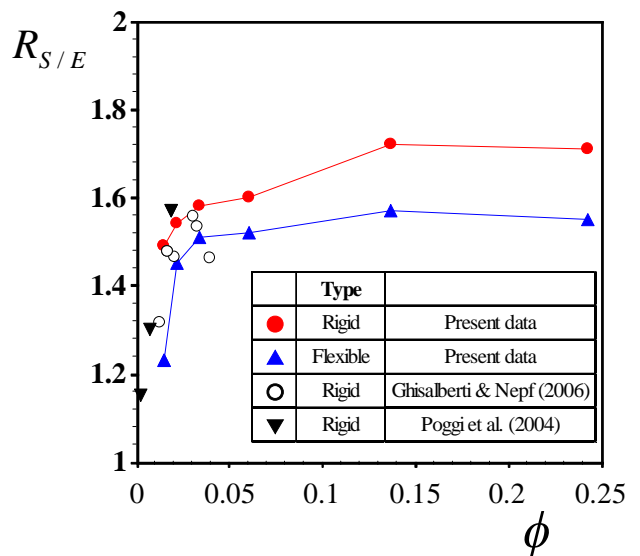

図-7 Sweep と Ejectionの寄与率比の植生密度 に対する変化

で運動量交換が活発である。これに対して， Monami ケースでは植生先端付近で $-\overline{u v} / U_{m}^{2}$ のピー クの值も小さくなっており，注目される。この結果 から藻波発生時には植生内部と外部との運動量交換 が小さくなる。これは柔軟植生が折れ曲がり，摇動 することで組織渦の発達が抑制されることが示唆し ている.これらの特性は Ghisalberti \& Nepf $(2006)^{20)}$ や著者ら (2016) ${ }^{9)}$ の結果と一致している.

植生流れでは Sweep, Ejection が発達し, 植生層内 外の運動量交換を支配することが知られている ${ }^{19)}$. 柔軟植生(Monami) と岡体植生流れにおいてこれら組 織乱流の運動量輸送への寄与を比較するために, 図 -6に同一の植生密度のケース $(\phi=0.061)$ につての 条件付きサンプリングしたレイノルズ応力分布を示 す. 条件付レイノルズ応力は次式で定義される.

$$
R S_{i}=\lim _{T \rightarrow \infty} \frac{1}{T} \int_{0}^{T} u(t) v(t) I_{i}(t) d t \quad(i=1,2,3,4)
$$

$(u, v)$ が $i$ 象限に存在するとき, $I_{i}(t)$ は 1 , それ以外 は 0 とする判別関数である。これらの各象限は次の 事象に対応している. (b)

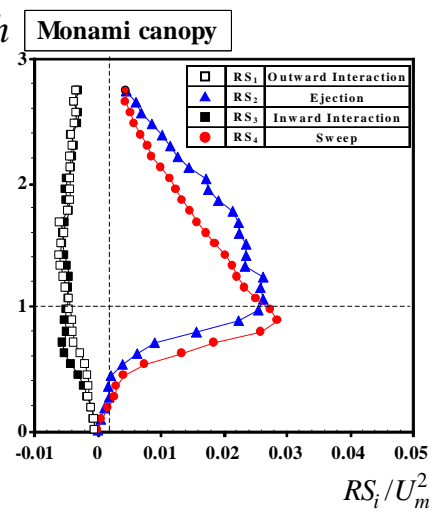

図-6 条件付きサンプリングしたレイノルズ応力分布

(a) Rigid Canopy, (b) Monami canopy

$$
\begin{array}{lll}
i=1 & (u>0, v>0) & : \text { Outward interaction } \\
i=2 & (u<0, v>0) & : \text { Ejection } \\
i=3 & (u<0, v<0) & \text { : Inward interaction } \\
i=4 & (u>0, v<0) & : \text { Sweep }
\end{array}
$$

図中の值は断面平均流速 $U_{m}$ で無次元化している. 図-6(a)の剛体植生ケースでは Sweep と Ejection 発生 時のレイノルズ応力分布は植生先端でピークをもつ. これに対して, Interactionの寄与を表す $R S_{1}, R S_{3}$ は植 生先端部で小さくなっている。これは植生先端部の Sweep と Ejection 構造が組織的で, Interactionの寄与 を含まないことを表している。また Sweep 発生時の ピーク值が最大であるため, 植生流れでは Sweep の 運動量輸送への寄与が大きいことがわかり，注目さ れる. 図-6(b)の柔軟植生ケースでも剛体植生と同様 に植生内部で Sweep が Ejection より卓越しているが, 剛体植生ほど Sweep と Ejectionの寄与の差はみられ ない.

図-6 の解析結果から植生流れでは Sweep が大きく, 植生内部への栄養塩や浮遊砂輸送などを支配すると 考えられるため, 植生の剛性や植生密度によって Sweep の強さがどう変化するのかは興味深いテーマ である。これを定量評価するため, 図-7 剛体植生と 柔軟植生について植生内部領域における Sweep と Ejectionのレイノルズ応力への寄与率を比較した. レイノルズ応力への寄与を比較するために次式で定 義される $R_{S / E}$ を用いた ${ }^{20)}$.

$$
R_{S / E}=\frac{1}{\overline{h_{d}}-h_{p}} \int_{h_{p}}^{\overline{h_{d}}}\left(R S_{4} / R S_{2}\right) d y
$$

$R_{S / E}$ の值が大きくなるほどSweepの寄与率が大きく なることがわかる。図から植生密度が増大すると $R_{S / E}$ が大きくなる傾向がみられ, 注目される.こ れより植生密度が増加すると植生先端部の流速シア 一が大きくなり，組織渦構造による鉛直方向の拡散 が大きくなる。結果としてSweepの寄与が大きくな 


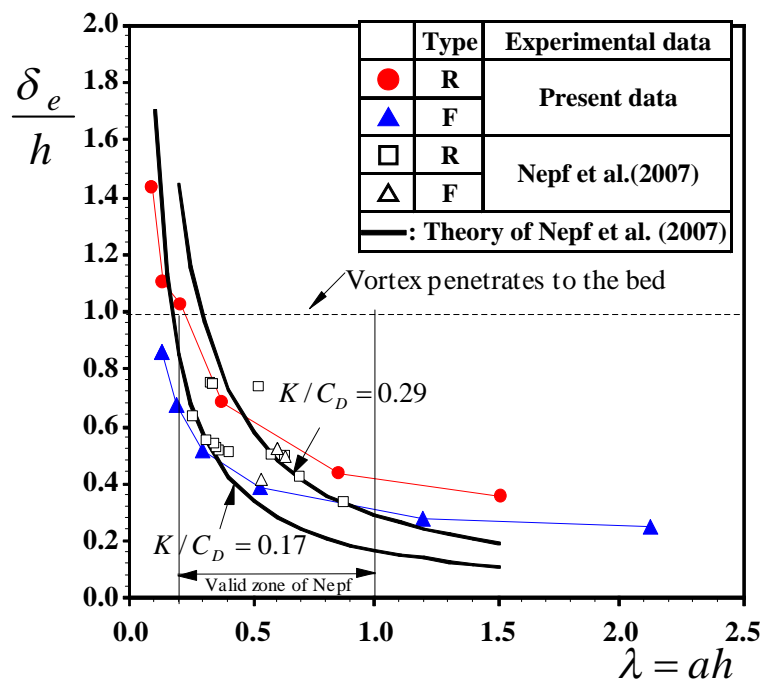

図-8 植生層内部への組織渦の浸透厚と植生密度の関係

っていることがわかる．この傾向はGhisalberti \& Nepf $(2006)^{20)}$ やPoggiら (2004) $)^{21)}$ の結果と一致する. 困か ら植生密度 $\phi=0.015 \sim 0.061$ の領域で $R_{S / E}$ が急激に 増加しており $\phi>0.061$ では一定值に近づく傾向がみ られるため, $\phi=0.015 \sim 0.061$ に遷移領域が存在する と考えられる.

また図から柔軟植生と比較して剛体植生ケースの $R_{S / E}$ が大きくなっているのが観察される。これは 図-5 に示すレイノルズ応力の浸透厚さ $\delta_{u v}=1-h_{p}$ の 傾向と一致しており，剛体植生ケースでは Sweep の 寄与が大きくなったために浸透厚さ $\delta_{u v}$ が増加した と考えられる.

\section{(3) 組織渦構造の比較}

上述のようにレイノルズ応力から浸透高さを評価 できる(図-5)が，浮遊砂が存在する実河川ではレイ ノルズ応力を高精度に計測することは困難な場合も 存在する。そこでNepf \& Ghisalberti (2008) ${ }^{17)}$ は KH不 安定渦の植生内部への浸透厚さ $\delta_{e}$ を次式で定義した.

$$
\delta_{e}=\frac{U(h)}{\partial U / \partial y_{y=h}}
$$

植生流れでは植生先端部で流速分布が変曲点をもつ ため， $\delta_{e}$ はせん断層の厚さを表している. Nepf \& Ghisalberti (2008) ${ }^{17)}$ は乱れエネルギ一収支方程式にお いて大規模渦スケールのエネルギー平衡を仮定する ことで次式を導出した。

$$
\frac{\delta_{e}}{h}=\frac{K}{C_{D} \lambda} \quad(\lambda=0.2-1.0)
$$

ここで $K$ は比例係数, $C_{D}$ は植生の抗力係数である. なお $\lambda=a h$ は Nepf \& Ghisalberti (2008) ${ }^{17)}$ の用いた植生 密度である。 Nepf \& Ghisalberti (2008) ${ }^{17)}$ の提案した
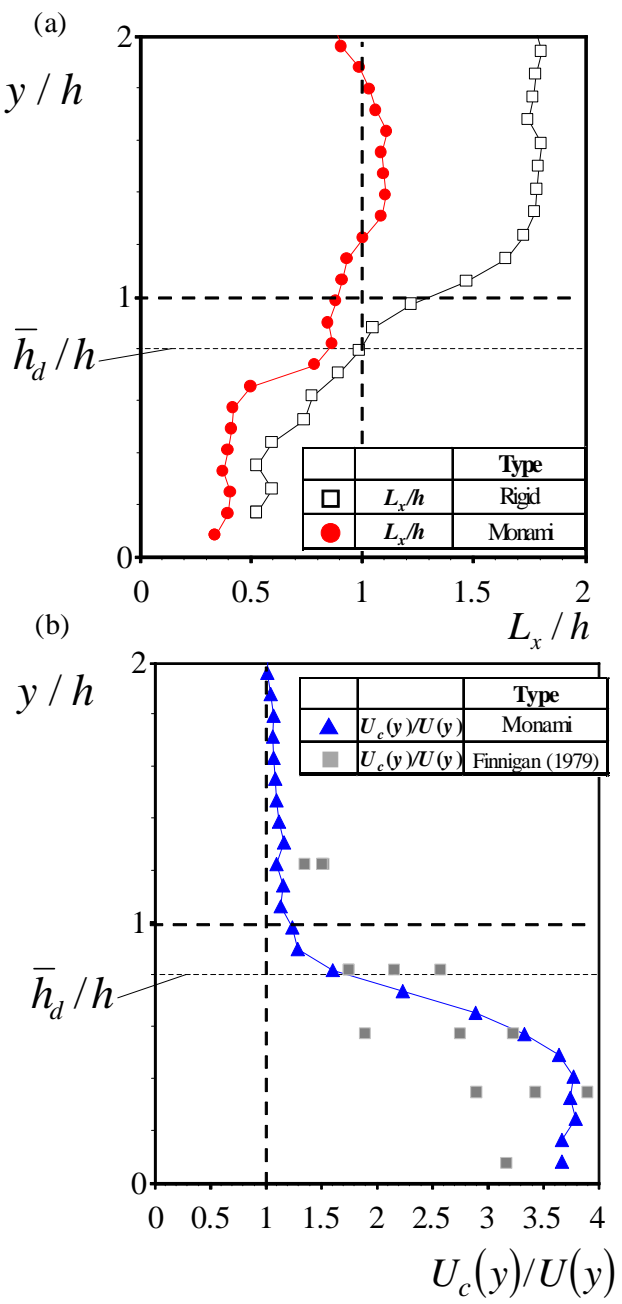

図-9 柔軟植生流れの組織渦構造 (a) 組織渦の長さ スケールの鉛直分布, (b) 組織渦の移流速度 の鉛直分布

式(9)は植生密度 $\lambda=0.2-1.0$ の範囲で成立する。図-8 は柔軟植生と剛体植生の組織渦の浸透厚さ $\delta_{e}$ を比 較したものである。本研究の $\delta_{e}$ の值は植生密度が 増加すると小さくなっており, Nepf \& Ghisalberti $(2008)^{17)}$ の結果と同じ傾向を示す. 本研究の $\delta_{e}$ は $\lambda=0.2-1.0$ の範囲で式(8)に一致している. また柔軟植 生より剛体植生ケースの $\delta_{e}$ が大きくなっているた め, 柔軟植生流れでは植生内部への渦の浸透が小さ く, 結果として混合層厚が小さくなると推測される. 本研究では PIV 法による多点計測を行っているた め, 組織渦のマクロスケールは流下方向の積分スケ 一ル $L_{x}$ として次式から評価することができる ${ }^{22)}$.

$$
L_{x}=\int_{0}^{\infty} \frac{\overline{u\left(x_{0}, y_{0}, t_{0}\right) \times u\left(x_{0}+\Delta x, y_{0}, t_{0}\right)}}{u^{\prime}\left(x_{0}, y_{0}\right) \times u^{\prime}\left(x_{0}+\Delta x, y_{0}\right)} d \Delta x
$$

ここで添字 0 は基準点および基準時刻を示す. 図9(a)に同一の植生密度のケース $(\phi=0.061)$ ケいて 
表-2 柔軟植生と剛体植生のパラメーターの比較

\begin{tabular}{|c||c|c|}
\hline \multicolumn{1}{|c||}{} & Rigid & Flexible \\
\hline \hline Flow resistance & Large & Small \\
\hline Shear instability $\Delta U$ & Large & Yes \\
\hline Mixing-layer type velocity profile & Yes & Mild small peak \\
\hline Reynolds stress & Large peak at vegetation edge & Small peak value \\
\cline { 2 - 3 } & Large peak value & Small \\
\hline Penetration of momentum within canopy & Large & Smaller contribution of Sweep \\
\hline Quadrant Reynolds stress $R S i$ & Larger contribution of Sweep & $L_{x}=1.0 h$ (Small) \\
\hline Mean-eddy scale $L_{x}$ & $L_{x}=1.5-2.0 h$ (Large) & $U_{c}=(1.5-2.0) U$ (Monami) at vegetation edge \\
\hline Convection velocity $U_{c}$ & $U_{c}=(1.5-2.0) U$ at vegetation edge & Small \\
\hline Coherent structure & Large & Small? \\
\hline Mass transport & Large? & \\
\hline
\end{tabular}

(a) Rigid vegetation

\section{Flow}

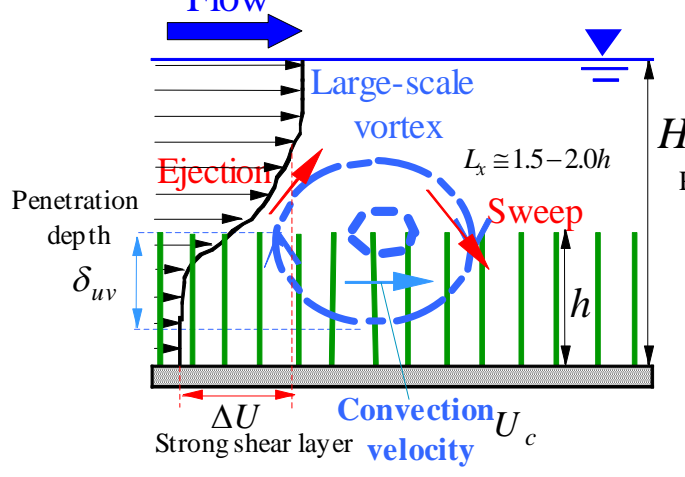

(b) Flexible vegetation

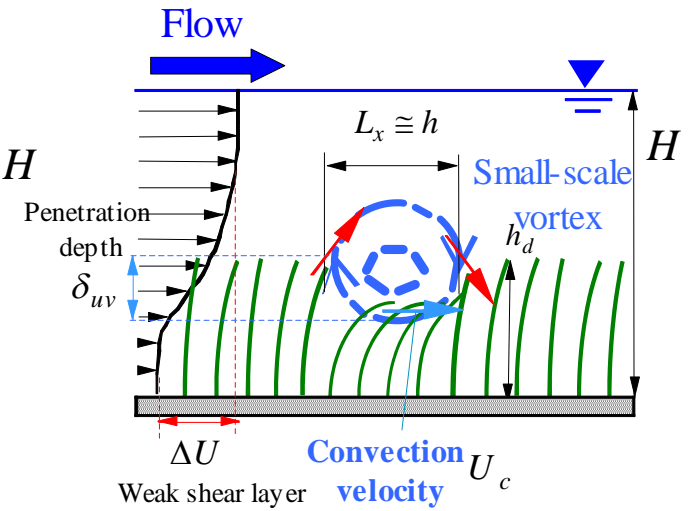

図-10 大規模渦構造比較の模式図 (a) 剛体植生流れ, (b) 柔軟植生流れ

剛体植生と柔軟植生流れの組織渦の長さスケールの 鉛直分布 $L_{x}(y)$ を示す．剛体植生では $L_{x} / h$ は 1.5-2.0 程度の值をもつ。対して，柔軟植生(Monami)では $L_{x} / h$ は植生先端部で 1.0 程度になり, 組織渦スケー ルが小さいことがわかった。また植生内部でも $L_{x} / h$ は 1.0 程度の值をもつ領域 $(0.6<y / h<1.0)$ が存在するた め，植生内部に組織渦が浸透していると考えられる.

また図-9(b)には柔軟植生流れにおける次式で計算 される組織渦の移流速度 $U_{c}(y)$ の鉛直分布を示寸.

$$
U_{c}=\frac{\Delta x}{\tau_{\max }}
$$

$\tau_{\text {max }}$ は固定点から流下方向に $\Delta x$ ずらした移動点に おいて時空間相関 $C_{u u}$ が最大となる遅れ時間である。 $U_{c}(y)$ の值は時間平均流速 $U(y)$ で無次元化している. 比較のため Finnigan (1979) ${ }^{23)}$ の大気植生の結果も併 示した. Finnigan (1979) ${ }^{23)}$ は熱線流速計の点計測デ ータを用いて, 次式から移流速度を算出した。

$$
U_{c}=\lambda \cdot f_{\text {peak }}
$$

ここで $f_{\text {peak }}$ は植生の摇動のピーク周波数， $\lambda$ は植生 の摇動の波長である. $U_{c} / U$ は植生内部で急激に増加 寸る傾向がみられ，注目される。これは時間平均流 速 $U(y)$ が植生内部で低減されるのに対して，大規模 渦の移流速度は植生内部に浸透しても低減しないた めだと考えられる. 植生先端では $U_{c}(y) / U(y)$ は 1.5 と なり, Finnigan (1979) ${ }^{23)}$ の結果と一致する. Finnigan $(1979)^{23}$ は大規模組織渦が通過すると, 植生内部で 正の流速変動が生じることを指摘した．この正の流 速変動によって植生がたわみ, 組織渦が移流される ことで植生の組織的摇動が流下方向に伝わって藻波 や穂波が発生するとしている.

\section{(4) 剛体植生と柔軟植生の比較のまとめ}

表-2はこれまでの解析で得られた剛体植生と柔軟 植生のパラメーターを比較してまとめたものである. 図-10には剛体植生と柔軟植生流孔の大規模渦構造 


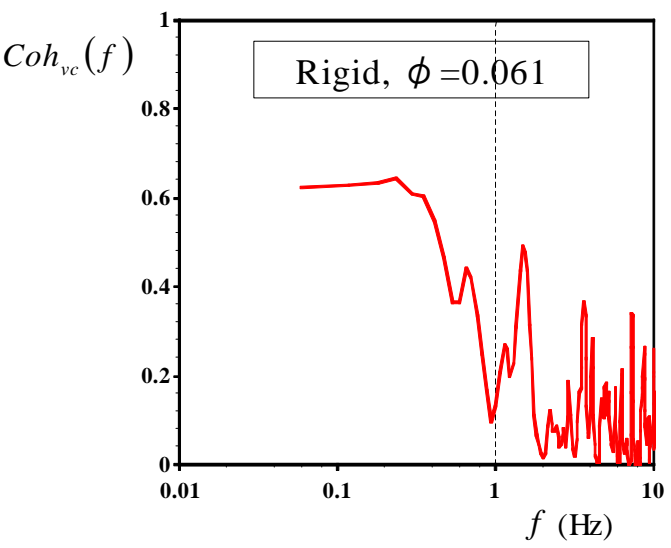

図-11 濃度一流速コヒーレンス

を比較した模式図を示す，植生流れでは平均流速分 布 $U(y)$ は植生先端で変曲点をもち, 混合層型の流速 分布をもつ(図-3)。特に剛体植生では流速シアーが 大きく, 植生先端部で大規模渦が発達する. 条件付 サンプリング解析(図-6)から植生流れではSweepの寄 与が大きくなり，植生内部へ運動量が輸送されてい ることがわかった。

これに対して，柔軟植生流れではレイノルズ応力 の值が小さく，植生層内部と外部の運動量交換が小 さい(図-5)。このため, 藻波発生時には組織渦の発 生が抑制され，スケールが小さくなると考えられる (図-9). Nepf \& Ghisalberti (2008) ${ }^{17}$ は移流速度 $U_{c}$ が 植生先端流速 $U_{h}$ より大きくなると藻波現象が発生 するとしている，藻波発生時には植生先端部におけ る移流速度 $U_{c}$ は(1.5-2.0) $U_{h}$ に達し，これは剛体植生 流れの值 ${ }^{16)}$ と同オーダーである。また柔軟植生が摇 動することで植生にかかる抗力が小さくなり，せん 断層の発達が抑制される. 結果, 組織渦のスケール が小さくなったと考えられる。

剛体植生で大規模組織構造が発達するため，植生 内部への栄養塩や浮遊砂などのスカラー輸送は剛体 植生の方が大きいと推測される。しかしながら，柔 軟植生と剛体植生流れの物質輸送メカニズムの違い については未解明点が多い。 Ghisalberti \& Nepf $\left.(2008)^{12}\right)$ は仮想粒子法を用いて，植生流れの物質輸 送メカニズムの数值予測を行っているが，実験デー タは得られていない，そこで次節では LIF 計測結果 を用いて柔軟植生と剛体植生流れの乱流拡散特性を 比較検討する。

\section{4. 植生流れの物質輸送メカニズム}

\section{（1）瞬間濃度-流速場}

本節では PIV と LIF 法を併用した瞬間流速-濃度同 時計測を行うことで組織渦構造の濃度輸送への寄与
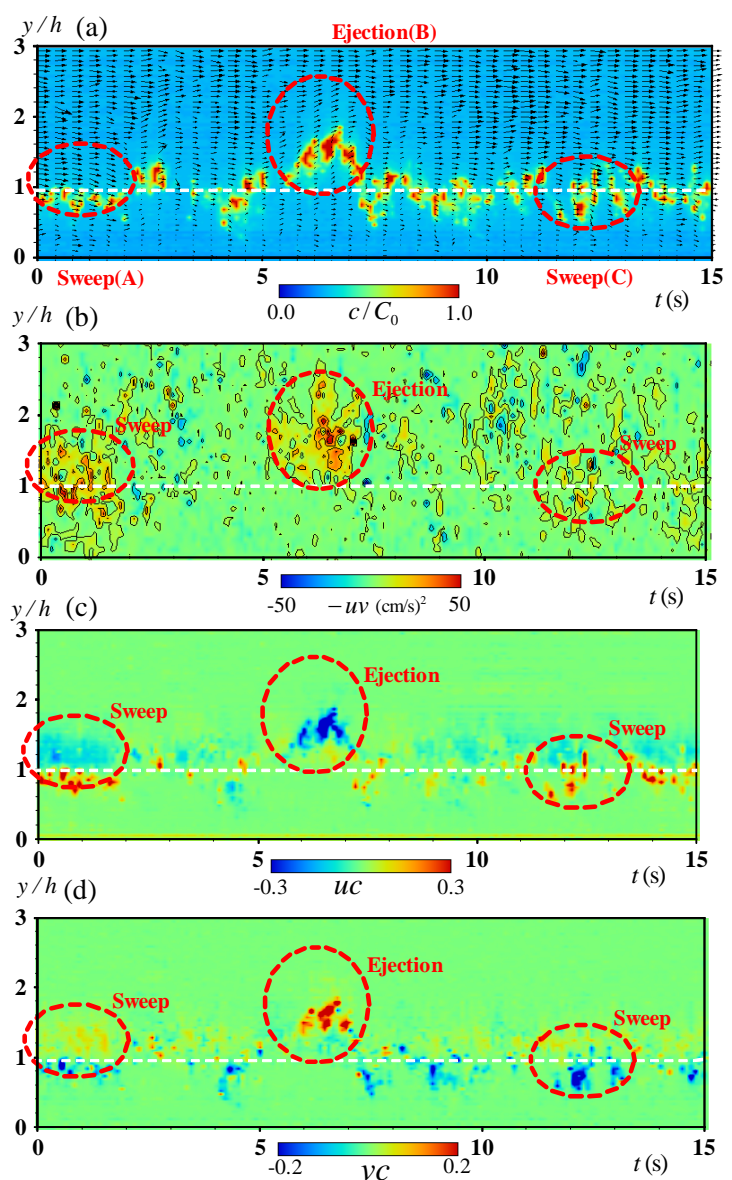

図-12 PIV/LIF 同時計測結果 (a) 瞬間流速ベクトル と瞬間濃度分布の時系列，(b) 瞬間レイノルズ 応力分布の時系列 (c)，(d) 流下方向と鉛直 方向の瞬間スカラーフラックスの時系列

を直接評価する。まず，濃度と流速のスケールごと の相関特性を明らかにするために, 図-11に $\phi$ $=0.061$, 剛体植生ケースの植生先端における濃度 $\tilde{c}$ と鈶直流速 $\tilde{v}$ のコヒーレンス $\operatorname{Coh}(f)$ を示す 7), 24).

$$
\operatorname{Coh}^{2}{ }_{v c}(f)=\frac{\left|S_{v c}(f)\right|^{2}}{S_{v}(f) S_{c}(f)}
$$

$S_{v c}(f)$ は変動量 $v(t)$ と $c(t)$ のクロススペクトルである 低周波側 $(f<1 \mathrm{~Hz})$ ではコヒーレンスは大きな值を もち，このスケールの濃度と鉛直流速は遅れ時間ゼ ロで強い相関をもっている。これに対して，高周波 側 $(f>1 \mathrm{~Hz})$ ではコヒーレンスは小さな值となり， このスケールの濃度と流速の相関はほとんどない。 すなわち，濃度と鉛直流速の相関は，その大部分が 大きい長さスケールの低周波渦によるものであり， 小さな長さスケール以下の高周波変動では，濃度と 流速はほとんど相関をもたない.

図-12(a)は剛体植生， $\phi=0.061$ ケースの瞬間流速 ベクトル $(\tilde{u}, \tilde{v})$ と瞬間濃度場 $\tilde{c}$ を $t=0.0(\mathrm{~s})$ から $t$ 

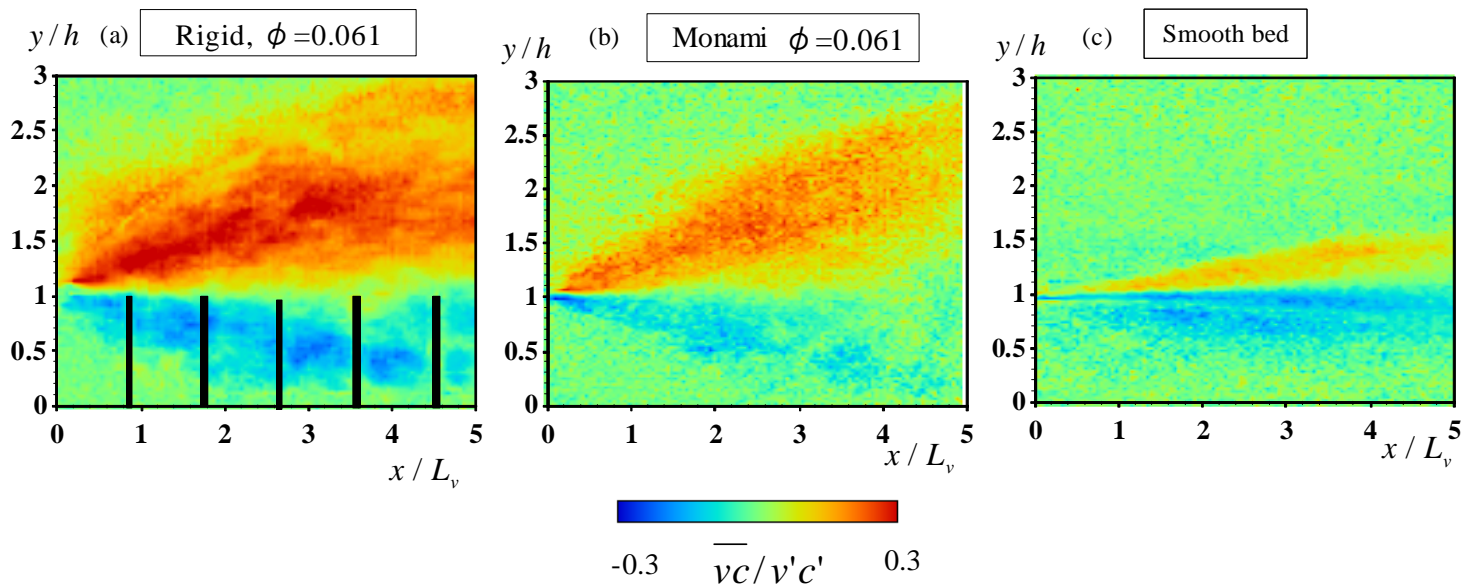

図-13 鉛直方向の乱流スカラーフラックスの鉛直面コンターの比較

(a) 剛体植生流れ, (b) 柔軟植生流れ, (c) 滑面開水路流れ
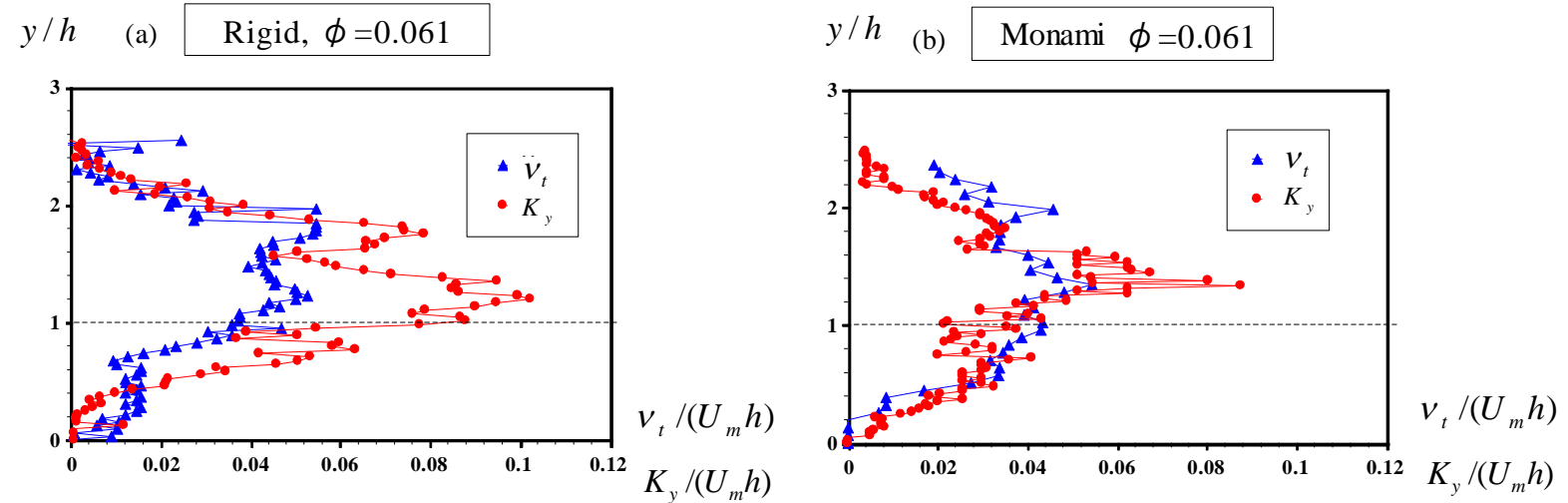

図-14 乱流拡散係数, 渦動粘性係数の分布 (a) 剛体植生流れ, (b) 柔軟植生流れ

$=15.0(\mathrm{~s})$ までの時系列に示したものである。図12(b)はそれぞれ，瞬間レイノルズ応力分布 $-u v(t)$ のコンター図である。これらの図は時刻を同期させ ている. $t=0.0(\mathrm{~s})$ では植生先端で高速流の下降ベク トル Sweep $(\mathrm{A})$ が発生し, 高濃度分布が植生内部に輸 送されているのが観察される. $t=6.0-7.0 \mathrm{~s}$ に植生外部 で低速流の上昇ベクトル Ejection(B)が観察され，注 入された染料が植生外部に輸送されている。 $t=$ 12.0-13.0s では再び Sweep $(\mathrm{C})$ が発生し，染料が植生 内部へ入り込んでいる。この特性は他の時刻および ケースにおいても観察され，植生開水路流れには Ejection から Sweep に移行する組織的な変動サイク ルが存在するようである。図-12(b)から Sweep, Ejection 発生時にそれぞれ植生内部と植生外部で瞬 間レイノルズ応力分布の局所的に大きな正值ピーク がみられ，瞬間レイノルズ応力の正值分布は大規模 組織乱流構造の発生領域と対応している.

図-12(c), (d) は流下方向と鉛直方向の瞬間濃度輸 送フラックス $u c(t)$ と $v c(t)$ のコンター図である. Sweep 発生時には瞬間濃度輸送フラックスはそれぞ
れ $u c>0(u>0, c>0), v c<0(v<0, c>0)$ となり，植 生内部への物質輸送が活発となっている。これに対 して, Ejection 発生時には $u c>0(u>0, c>0)$, $v c<0(v<0, c>0)$ で植生外部へ染料が輸送されてい る。また図-11(b)瞬間レイノルズ応力と瞬間濃度輸 送フラックスのピーク位置とが一致することから運 動量輸送と物質輸送に高い相関があることが示唆さ れ，注目される。

\section{(2) 速度ースカラー結合統計量}

乱流拡散現象を理解し，かつ予測するには速度場 とスカラー場の結合統計量の特性を明らかにするこ とが重要である。本研究では瞬間流速-濃度同時計 測を行っているため, 物質輸送フラックス $v c(t)$ を直 接計算し，鉛直方向の物質輸送効率を評価すること が可能である。乱流スカラーフラックスは以下のよ うに無次元化して相関係数の形で表現することがで きる。

$$
\rho_{v, c}=\frac{\overline{v c}}{v^{\prime} c^{\prime}}
$$


(a) Rigid, $\phi=0.061$

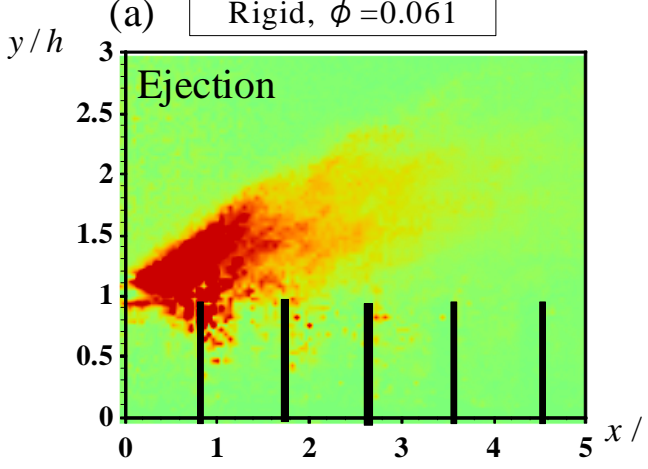

(b)

$y / h$

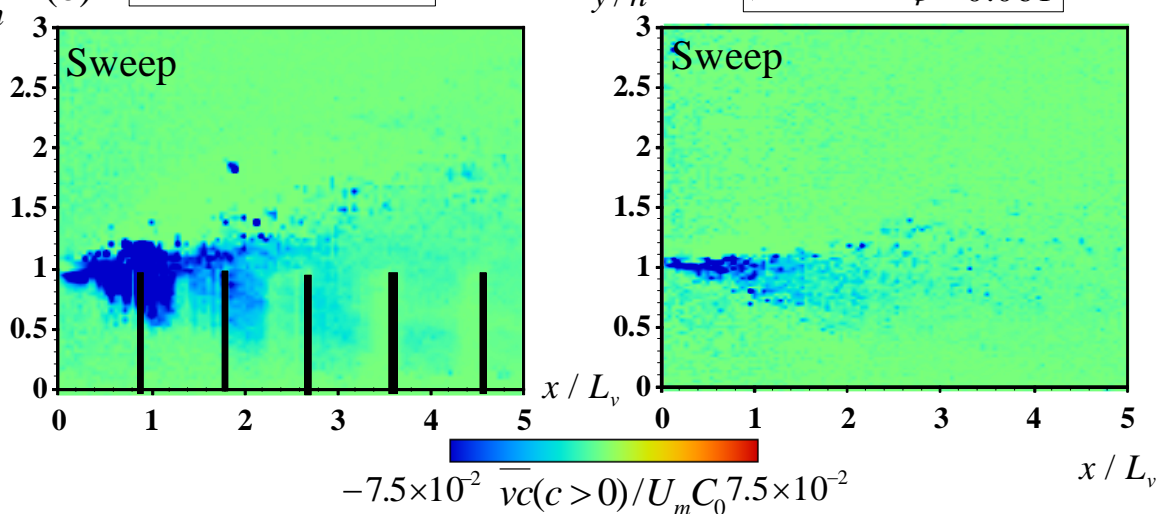

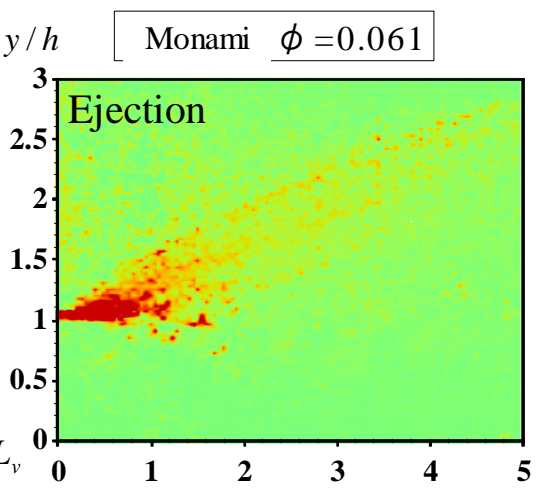

$x / L_{v}$

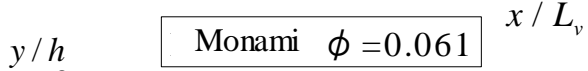

図-15 条件付サンプリングした鉛直方向のスカラーフラックスの鉛直面コンター (a) Ejection 発生時, (b) Sweep 発生時

相関係数の形にすることで $v, c$ の絶対值の影響を 受けずに，流速一濃度の相関を評価できる。ここで ダッシュは変動強度を意味する. 図-13 は $\phi=0.061$ の柔軟植生(Monami) と剛体植生, 滑面 $(\phi=0.0)$ の鉛 直方向の物質輸送フラックス $\overline{v c} / v^{\prime} c^{\prime}$ のコンター図で ある. 滑面 $(\phi=0.0)$ ケースでは水深 $H=21 \mathrm{~cm}$ としてい るため, 柔軟植生長さ $h=7 \mathrm{~cm}$ で無次元化している. 剛体植生と柔軟植生ヶースにおいて植生先端部を中 心として上下に正負分布が分かれている。これは植 生層内部と外部で物質輸送メカニズムが異なるため である. すなわち, 図-12 のように植生先端部から 植生内部へは高速流の下降ベクトル Sweep によって 高濃度の染料が輸送されるため $(v<0, c>0)$, 負值分布 $\overline{v c}<0$ がみられる. これに対して, 植生外 部では低速流の上昇ベクトル Ejection によって染料 が水面側に輸送されるため $(v>0, c>0)$, 正值 分布 $\overline{v c}>0$ が現れる.

特に剛体植生で柔軟植生(Monami)より大きな正值 と負值分布がみられ，興味深い。これは図-5レイノ ルズ応力分布 $-\overline{u v} / U_{m}^{2}$ と一致しており, 剛体植生で 流速シアーが大きく大規模な組織構造が発達し，植 生内部と植生外部により多くの濃度が輸送されるた めである.
レイノルズ応力分布や濃度一流速の相関值は勾配 拡散モデルによって次式で表せる.

$$
-\overline{u v}=v_{t} \partial U / \partial y, \quad-\overline{v c}=K_{y} \partial C / \partial y
$$

ここで $v_{t}$ は渦動粘性係数， $K_{y}$ は鉛直方向の乱流拡 散係数. 図-14 は式(15)より求めた $\phi=0.061$ の柔軟植 生(Monami) と剛体植生の $v_{t}$ と $K_{y}$ の鉛直分布を比較 したものである. $K_{y}$ の鉛直分布は $v_{t}$ の分布と類似 する. 寸なわち, 植生内部から植生先端にかけて増 加し, 水面付近の領域で減少する。剛体植生ケース では混合層領域でシュミット数のオーダーが $S_{c}=v_{t} / K_{y}=0.5-1.0$ となっている. これに対して, 柔軟植生ケースでは剛体植生ケースよりも乱流拡散 係数が小さい。図-13, 図-14 の結果より柔軟植生流 れでは剛体植生より鉛直方向の物質交換効率が小さ いことが確認できた.

\section{(3) 条件付サンプリング解析}

Raupach ら (1996) ${ }^{25) や ~ G h i s a l b e r t i ~ \& ~ N e p f ~(2006) ~}{ }^{20)}$ は 植生流れではSweep, Ejectionの物質輸送への寄与が 大きいことを示唆しているが，実験データは得られ ていない，そこで本研究では瞬間流速を用いて条件 

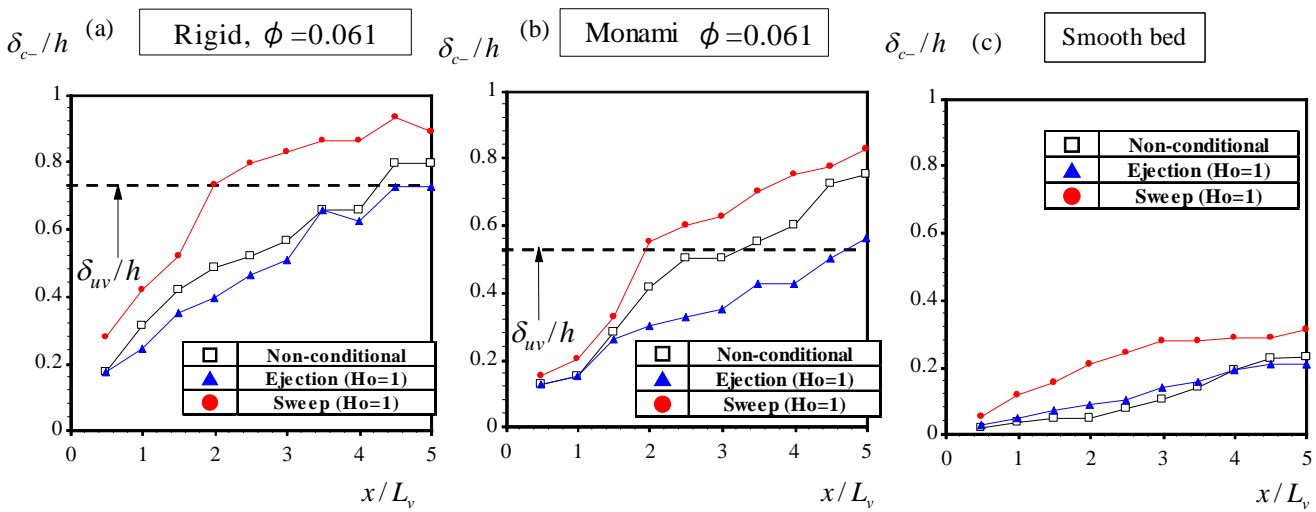

図-16 鉛直方向のスカラーフラックスの植生内部への浸透厚さ

(a) 剛体植生流れ, (b) 柔軟植生流れ, (c) 滑面開水路流れ

付解析を行う。

図-15(a), (b)はそれぞれ $\phi=0.061$ の剛体植生と柔軟 植生ケースについてホール值 Ho を用いて Ejection, Sweep 発生時のみを抽出したスカラーフラックス $\overline{v c}$ (Ejection: $\mathrm{Ho}=1), \quad \overline{v c}$ (Sweep: $\mathrm{Ho}=1)$ のコンターを示す. Ejection 発生時には $\overline{v c}$ (Ejection: Ho=1)が Mixing-layer zone の下端から上端までの領域 $(y / h=0.5-1.7)$ で大き くなっており，Ejection による鉛直方向の輸送が活 発である. Sweep 発生時には $\overline{v c}$ (Sweep: Ho=1) は Mixing-layer zone の中心から下端にかけて大きな值 をもつ。植生内部では $\overline{v c}($ Sweep: Ho=1)は $\overline{v c}($ Ejec-

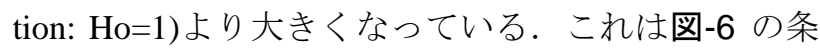
件付サンプリング解析の結果と対応しており，植生 流れにおいて Sweep の物質輸送への寄与が大きいこ とが評価できた。これらの結果は Raupachら $(1996)^{25)}$ の植生流れの既往研究の知見と一致してい る.

Nepf \& Ghisalberti (2008) $)^{17)}$ はレイノルズ応力分布 を用いて，運動量の浸透厚さ $\delta_{u v}$ を定義した(図-5). すなわち植生内部でレイノルズ応力のピーク值の $10 \%$ となる高さを $h_{p}$ とし, 浸透厚さは $\delta_{u v}=1-h_{p}$ で計算される。 $\overline{v c}$ も植生先端で負值ピークをもつ ため, スカラーフラックスの植生内部への浸透厚さ $\delta_{c}$ も同様に定義できる. 図-16 は鉛直方向の物質輸 送フラックス $\overline{v c}(c>0)$ の植生内部への浸透厚さ $\delta_{c}$ を示す. 図中には比較のため運動量の浸透厚さ $\delta_{u v}=1-h_{p}$ を併示している. $\delta_{c}$ (Non-conditional)は ノズル位置から離れると増加する傾向がみられ， $x / L_{v}=4.0$ において運動量の浸透厚 $\delta_{u v}$ と同程度の大き さをもつ。剛体植生流れと比較して柔軟植生や Smooth bed では $\delta_{c}$ が小さいため, 鉛直方向の拡散が 小さい. Peralta ら(2008) ${ }^{26)}$ は柔軟植生と比較して剛 体植生では植生内部に流砂などがたまりやすいとし
ているが，これは本研究の結果と一致しており，注 目される. Sweep 発生時には Non-conditional より $\delta_{c}$ が大きく, スカラーフラックスの植生内部への浸透 が大きくなることがわかる.

\section{5. 結論}

本研究では柔軟植生流れにおける組織渦による物 質輸送メカニズムを考察した。前半部では植生の剛 性による組織渦の特性，スケールの違いを比較した。 後半部では PIV/LIF 法を用いて瞬間濃度一流速の同 時計測し，濃度一流速相関特性を定量評価した。さ らにスカラーフラックスを直接計算し, 柔軟植生と 剛体植生の物質輸送特性を比較検討した。以下に主 要なポイントをまとめて列挙する.

1) 剛体植生では流速シアーが大きく, 植生先端部 で大規模渦が発達する。剛体植生流れでは柔軟 植生より Sweep の寄与が大きくなり，植生内部 へより多くの運動量が輸送される.

2) 柔軟植生流れではレイノルズ応力の值が小さく, 植生層内部と外部の運動量交換が小さい. 柔軟 植生が摇動することで植生にかかる抗力が減少 し，せん断層の発達が抑制される。その結果， 組織渦の浸透厚さや長さスケールも小さくなる.

3) コヒーレンス解析結果から濃度と鉛直流速の相 関は，その大部分が大きい長さスケールの低周 波渦によるものであり，小さな長さスケール以 下の高周波変動では，濃度と流速はほとんど相 関をもたない.

4) Ejection / Sweep 発生時に瞬間スカラーフラック スがピークとなる。ピーク高さは最大瞬間レイ ノルズ応力の発生ポイントと一致することから 運動量輸送と物質輸送に高い相関があることが 
示唆される

5）鉛直方向のスカラーフラックスの分布は, 植生 層内部と外部で物質輸送メカニズムが異なるた め植生先端部を中心として上下に正負の 2 極分 布となる。剛体植生ケースでは柔軟植生 (Monami)より大きな正值と負值分布がみられ， 柔軟植生流れでは剛体植生より鉛直方向の物質 交換効率が小さい.

6) PIV/LIF 同時計測結果から植生流れの乱流拡散 係数を評価することができた．剛体植生ケース では混合層領域で乱流拡散係数が大きくなり， シュミット数 $S_{c}=v_{t} / K_{y}=0.5-1.0$ となった。 ま た柔軟植生ケースでは剛体植生ケースより乱流 拡散係数が小さくなることがわかった。

7) 剛体植生ケースでは Sweep 発生時のスカラーフ ラックスの植生内部への浸透厚が大きくなるた め, Sweep によって植生内部へのスカラー輸送 が促進される。

\section{参考文献}

1) 島谷幸宏：多自然型川づくりの役割と課題, http://www7.civil.kyushu-u.ac.jp/ryuuiki/5\%20tasizen.pdf (2011 年 1 月現在)

2) Kouwen, N. and Unny, T. E. : Flexible roughness in openchannels, ASCE J. Hydraulics Div., Vol. 99 (HY5), pp. 713727, 1973.

3) 清水義彦, 辻本哲郎, 中川博次 : 直立性植生層を伴 う流れ場の構造に関する実験的研究，土木学会論文 集，第 447 号/II-19, pp. 35-44, 1992.

4) 大本照憲，田中貴幸，矢北孝一：植生群落を伴う開 水路流れにおける水面変動と流速変動の相互作用, 水工学論文集，第 49 巻, pp. 499-504, 2005.

5）池田駿介, 金沢稔, 太田賢一：可撓性を有する沈水 性植生層上の組織渦の 3 次元構造と穂波の発生，土木 学会論文集，第 515 号/II-31, pp. 33-43, 1995.

6) 辻本哲郎, 北村忠紀, 中川博次 : 柔軟な植生粗度を 伴う流れに関する研究, 水工学論文集, 第 39 巻, pp. 519-524, 1995.

7) Siniscalchi, F. and Nikora, V. : Dynamic reconfiguration of aquatic plants and its interrelations with upstream turbulence and drag forces, J. of Hydraulic Res., Vol. 51, pp. 4655, 2013.

8) Marjoribanks, T. I., Hardy, R. J., Lane, S. N. and Parsons, D. R. : Does the canopy mixing layer model apply to highly flexible aquatic vegetation? Insights form numerical modelling, Environmental Fluid Mechanics, Vol. 17, pp. 277-301, 2017.

9) Okamoto, T., Nezu, I. and Sanjou, M. : Flow-vegetation interactions: length-scale of the "monami" phenomenon, J. of Hydraulic Res., Vol. 54, pp. 251-262, 2016.

10) Rahman, S. and Webster, D. R. : The effect of bed roughness on scalar fluctuations in turbulent boundary layers, Experiments in Fluids, Vol. 38, pp. 372-384, 2005.
11) Reidenbach, M. A., Koseff, J. R. and Monismith, S. G. : Laboratory experiments of fine-scale mixing and mass transport within a coral canopy, Physics of Fluids, Vol. 19, 075107, 2007.

12) Ghisalberti, M. and Nepf, H. : Shallow Flows over a permeable medium: The hydrodynamics of submerged aquatic canopies, Transp. Porous. Med., Vol. 78, pp. 385-402, 2008.

13) Le Bouteiller, C. and Venditti, J. G. : Sediment transport and shear stress partitioning in a vegetated flow, Water Resources Research, Vol. 51, pp. 2901-2922, 2015.

14) Velasco, D., Bateman, A., Redondo, J. and Demedina, V. : An open channel flow experimental and theoretical study of resistance and turbulent characterization over flexible vegetated linings, Flow Turbulence and Combustion, Vol. 70, pp. 69-88, 2003.

15) Wilson, C. A. M. E., Stoesser, T., Bates, P. D. and Batemann Pinzen, A. : Open channel flow through different forms of submerged flexible vegetation, J. of Hydraulic Engineering, Vol. 129, pp. 847-853, 2003.

16) Nezu, I. and Sanjou, M. : Turbulence structure and coherent motion in vegetated canopy open-channel flows, J. of Hydro-Environment Res., IAHR, Vol. 2, pp. 62-90, 2008.

17) Nepf, H. M. and Ghisalberti, M. : Flow and transport in channels with submerged vegetation, Acta Geophysica, Vol. 80, pp. 99-128, 2008.

18) Ho, C. M. and Huerre, P. : Perturbed free shear layers, Ann. Rev. Fluid Mech., Vol. 16, pp. 365-424, 1984.

19) Ghisalberti, M. and Nepf, H. : The limited growth of vegetated shear layers, Environ. Fluid Mech., Vol. 6, pp. $277-$ $301,2004$.

20) Ghisalberti, M. and Nepf, H. : The structure of the shear layer in flows over rigid and flexible canopies, Water Resource Research, Vol. 40, W07502, 2006.

21) Poggi, D., Porpotato, A. and Ridolfi, L. : The effect of vegetation density on canopy sub-layer turbulence, BoundaryLayer Meteorology, Vol. 111, pp. 565-587, 2004.

22) Brunet, Y., Finnigan, J. J. and Raupach, M. R. : A wind tunnel study of air flow in waving wheat: single-point velocity statistics, Boundary-Layer Meteorology, Vol. 70, pp. 95132, 1994.

23) Finnigan, J. : Turbulence in waving wheat; Mean statistics and Honami, Boundary-Layer Meteorology, Vol. 16, pp. 181-211, 1979.

24) Biltoft, C. A. and Pardyjak, E. R. : Spectral coherence and the statistical significance of turbulent flux computations, $J$. of Atmospheric and Oceanic Technology, Vol. 26, pp. 403410, 2009.

25) Raupach, M. R., Finnigan, J. J. and Brunet, Y. : Coherent eddies and turbulence in vegetation canopies: The mixinglayer analogy, Boundary Layer Meteorology, Vol. 78, pp. 351-382, 1996.

26) Peralta, G., van Duren, L. A., Morris, E. P. and Bouma, T. J. : Consequences of shoot density and stiffness for ecosystem engineering by benthic macrophytes in flow dominated areas: a hydrodynamic flume study, Mar. Ecol. Prog. Ser., Vol. 368, pp. 103-115, 2008.

(2017. 4. 25 受付) 


\section{EFFECT OF COHERENT TURBULENCE STRUCTURE ON VERTICAL MASS TRANSPORT IN CANOPY OPEN-CHANNEL FLOWS WITH FLEXIBLE VEGETATIONS}

\section{Takaaki OKAMOTO and Michio SANJOU}

Significant contributions of flow and turbulence to ecology related to aquatic benthic organism has been widely reported. Aquatic vegetation is one of environmental variables that influence turbulence and the ecological condition of rivers. Coherent turbulent motions are generated near the vegetation edge and these large-scale coherent eddies control the vertical exchange of mass and momentum between the over- and within-canopies. However, the effect of the submerged vegetation on the turbulent mixing process has not been fully investigated. Therefore, continuous dye-injection experiments were conducted to evaluate the vertical mass transport in open-channel flow with rigid vegetation models. The combination of PIV (Particle Image Velocimetry) and planar LIF (Laser-induced Fluorescene) technique is applied to reveal mass transfer in the vegetated open-channel flows. Two-dimensional data allow the identification of coherent structures and quantification of the vertical mass transport. The results revealed that the vortex structure lose coherence for flexible vegetation flow as compared to rigid vegetation flow. The values of the turbulence diffusivity become larger for rigid vegetation flow than those for flexible vegetation flow. 